\title{
高脂肪食飼育ラットの脂質代謝改善に及ぼす サーファクチンと納豆の相乗効果
}

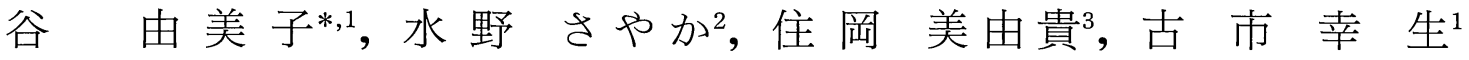
大 島 芳 文 ${ }^{4}$, 伏 見 宗 士 ${ }^{4}$, 垣 沼 淳 司 ${ }^{2}$

(2005 年 9 月 12 日受付；2006 年 7 月 15 日受理)

\begin{abstract}
要旨：ラットを用いて，コレステロール添加高脂肪食を飼料として与えた対照群，対照群の飼料の $53 \%$ （w/w）を納豆の凍結乾燥品で置換して組成を対照群の飼料とそろえた納豆群，およびおのおのにサーファ クチン $0.3 \%$ を添加した飼料を与えたサーファクチン群，サーファクチン・納豆群の 3 試験群，計 4 群につ いて脂質代謝を調べ，サーファクチン含量の高い納豆開発の可能性を検討した。その結果，1）血清総コレ ステロール，動脈硬化指数，トリグリセリドとも三つの試験群で有意に低下または低下の傾向がみられ，総 コレステロールではサーファクチンと納豆の相乗効果が認められた。2）肝臓の総脂質はサーファクチン・ 納豆群で，コレステロールはサーファクチン群とサーファクチン・納豆群で，トリグリセリドはいずれの試 験群でも低值を示した。3）糞中コレステロール排泄率はサーファクチン・納豆群で, 胆汁酸排泄量はすべ ての試験群で増加し, 肝臓の脂肪酸合成系は納豆群とサーファクチン・納豆群で低下した。以上の結果か ら，コレステロール添加高脂肪食飼育ラットにおいて，サーファクチンと納豆が，血清総コレステロール， 肝臓トリグリセリドの低下および䔬中コレステロール排泄率の増加に相乗作用を示すことがわかった。
\end{abstract}

キーワード：サーファクチン，納豆，血清脂質，肝臓脂質，相乗効果

微生物によって生産される界面活性剤はバイオサー ファクタントと呼ばれ, 1960 年代後半から発見されて きている。サーファクチンは, 1968 年に垣沼らによっ て枯草菌 (Bacillus subtilis) 培養液から結晶化され命 名された代表的なバイオサーファクタントで, 3-オキ シ-13-メチルテトラデカノイルヘプタペプチドラクトン (Figure 1) の構造をもつぺプチドリピドであり ${ }^{12)}$, 強 力な界面活性作用をもつにもかかわらず，タンパク質変 性作用の弱いことが特徵である ${ }^{2) 31}$ 。サーファクチンの 脂質代謝系への影響としては，ラットでコレステロール の吸収阻害および血漿, 肝臓のコレステロール低下作用 が明らかとなっている゙ 。

一方枯草菌の一種の納豆菌を用いて大豆から得られる 発酵食品の納豆は, 日本古来より摂取されており, 近年 代表的な健康食品の一つとして注目を集めている。その 原料の大豆については, アミノ酸類, 消化過程に生成す る高分子のタンパク質未消化物およびサポニン，イソフ ラボンなどの微量成分の作用による血清 ${ }^{5-7)}$ および肝臓 コレステロールの低下 ${ }^{8-10)}$, LDL/HDL 比の改善8)99,
胆汁酸排泄の促進 ${ }^{8-11)}$, コレステロールの吸収抑制 ${ }^{12) 13)}$ など脂質代謝改善作用について多くの報告がある。納豆 には以上の大豆のもつ脂質代謝改善作用に加えて, さら にナットウキナーゼによる血栓防止作用, LDL 酸化の 抑制作用 ${ }^{14-16)}$ など健康の維持増進, 生活習慣病予防に 対する有効性が示唆されている。

納豆菌はサーファクチン産生能をもっているがその生 産性は枯草菌に比べて著しく低く (垣沼, 未発表), サー ファクチン合成酵素遺伝子の発現量も低い17) といわれ ているので, 今回用いた納豆にはサーファクチンはほと んど含まれていないと考えられる。そこで本研究では サーファクチンと納豆を同時に投与した場合の脂質代謝 に及ぼす相乗効果の有無を調べ，サーファクチン含量の 高い納豆開発の可能性を検討した。

\section{実 験 方 法}

\section{1. 動物, 飼料, 飼育方法および試料採取法}

9 週歯（体重 $270 \mathrm{~g}$ 前後）の Sprague-Dawley (SD) 系 雄ラット（日本エスエルシー(株）24 匹を用いて，対照

\footnotetext{
* 連絡者・別刷請求先

1 名古屋女子大学家政学部 (467-0003 愛知県名古屋市瑞穂区汐路町 3-40)

2 元 名古屋女子大学

3 三重大学生物資源学部（514-8507 三重県津市栗真町屋町 1577）

4 株式会社ミツカングループ本社中央研究所 (475-8585 愛知県半田市中村町 2-6)
} 


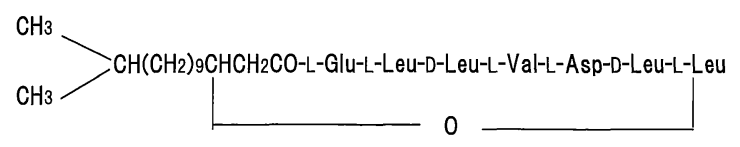

Figure 1 Structure of surfactin.

Table 1 Composition of the experimental diets.

\begin{tabular}{lcc}
\hline \multicolumn{1}{c}{ Ingredient } & $\begin{array}{c}\text { Control } \\
\text { group } \\
(\%)\end{array}$ & $\begin{array}{c}\text { Natto } \\
\text { group } \\
(\%)\end{array}$ \\
\hline Natto (freeze-dried) $^{1}$ & - & 53 \\
Cornstarch $^{2}$ & 51.75 & 33.45 \\
Casein $^{2}$ & 20 & - \\
Lard $^{3}$ & 20 & 7.3 \\
Cellulose $^{2}$ & 2 & - \\
Mineral mixture $^{4}$ & 4 & 4 \\
Vitamin mixture (AIN-76) $^{5}$ & 1 & 1 \\
Cholesterol $^{6}$ & 1 & 1 \\
Sodium cholate $^{6}$ & 0.25 & 0.25 \\
\hline \hline
\end{tabular}

${ }^{1}$ Central Res. Inst., Mitsukan Group Co., Ltd. ${ }^{2}$ Japan CLEA Co., Tokyo. ${ }^{3}$ Yoneyama Reagent Industries Co., Osaka. ${ }^{4}$ Oriental Yeast Co., Tokyo. This is identical to Harper's mixture. ${ }^{18)}{ }^{5}$ Oriental Yeast Co., Tokyo. ${ }^{6}$ Kanto Chemical Co., Tokyo.

群，サーファクチン群，納豆群，サーファクチン・納豆 群の 4 群に分け, 各群 6 匹として 4 週間飼育した。ラッ トは購入後，(株)日本クレアの粉末飼料（CE-2）で 3 日 間予備飼育した。その後, 対照群はコレステロール添加 高脂肪食で，納豆群は納豆を含むコレステロール添加高 脂肪食で飼育した（Table 1)。サーファクチン群および サーファクチン・納豆群は，それぞれ対照群および納豆 群の飼料にサーファクチン $0.3 \%$ （純アルコールに溶解 して添加）を加えたもので飼育した。

納豆は(株)ミツカングループ本社中央研究所の凍結乾燥 品（商品名 朝日フレシア水戸こつぶ）を製粉器 (Power grinder T-351, King tool Co.）で粉砕して用いた。納豆 群の飼料は凍結乾燥納豆の組成（Table 2) を考慮して, 対照群と同様の組成になるようにタンパク質，脂肪，セ ルロースの含量を調整し，コーンスターチで 100\%とし た。飼育は対照群のエネルギー摂取量にそろえてぺア フィーディングし，飲水は自由摂取とした。

サーファクチンは，B. subtilis IAM1213 の培養液か ら既報 ${ }^{1)}$ の方法を若干改変した方法により結晶を得て使 用した。

飼育条件および血清採取，肝臓・脂肪組織の摘出，糞 の採集方法は既報 ${ }^{19)}$ と同様である。動物実験は「名古 屋女子大学動物実験指針」ならびに「実験動物の飼養及 び保管等に関する基準」（昭和 55 年 3 月総理府告示 6 号）に準じて実施した。
Table 2 Composition of freeze-dried natto. ${ }^{1}$

\begin{tabular}{lc}
\hline \hline \multicolumn{1}{c}{ Component } & $\%$ \\
\hline Moisture & 4.0 \\
Protein & 37.9 \\
Fat & 23.9 \\
Carbohydrate & 12.7 \\
Dietary fiber & 17.3 \\
Ash & 4.2 \\
\hline \hline
\end{tabular}

${ }^{1}$ Central Res. Inst., Mitsukan Group Co., Ltd. See legend for Table 1 .

\section{2. 分 析}

血清については総コレステロール (T-chol), HDLコレステロール (HDL-chol)，トリグリセリド (TG)を， 肝蔵については総脂質 (TL), Chol, TG, アセチル $\mathrm{CoA}$ カルボキシラーゼ[EC 6.4.1.2] (ACC) 活性, 脂肪 酸合成酵素（FAS）活性, 肝トリグリセリドリパーゼ [EC 3.1.1.33] (HTGL) 活性, HMG-CoA レダクター ゼ [EC 1.1.1.34] の mRNAの発現量, $7 \alpha$-ヒドロキシ ラーゼ [EC 1.14.13.17］の mRNA の発現量を，脂肪組 織についてはリポプロテインリパーゼ [EC 3.1.1.34] (LPL) 活性, LPLの mRNA の発現量を, 霟について はChol および胆汁酸を測定した。

2.1 血清および肝臓脂質の分析 既報 ${ }^{19)}$ と同様に, 血清の T-chol, HDL-chol, TG おょよ゙肝藏の TL, Chol を測定した。肝臓のTGは，クロロフォルム・メ夕 ノール混液 $(2: 1 \mathrm{v} / \mathrm{v})$ による抽出液を蒸発乾固後, 残 渣をイソプロピルアルコールに溶解して, 和光純薬工業 (侏)のトリグリセライド E-テストワコーを用いて測定し た。動脈硬化指数（AI）は（T-chol-HDL-chol）/HDLchol から算出した。

2.2 肝臓の脂質代謝系酵素活性の測定 FAS は既 報 ${ }^{20)}$ と同様に Nepokroeff et $a l .{ }^{21)}$ および仲佐ら ${ }^{22)}$ の方 法に準じて測定した。1 unit は $30^{\circ} \mathrm{C} て ゙ 1$ 分間に $1 \mu \mathrm{mol}$ の NADPHを減少させる酵素活性とした。ACC は既 報20) と同様に Tanabe et $a l .{ }^{23)}$ および仲佐ら ${ }^{22)}$ の方法に 準じて測定した。 1 unit は $37^{\circ} \mathrm{C} て ゙ 1$ 分間に $1 \mu \mathrm{mol} の$ $\mathrm{NADH}$ を減少させる酵素活性とした。HTGL は Morimoto et al. の方法 ${ }^{24)}$ を一部改変した既報 ${ }^{19)}$ と同様に測 定した。酵素活性は 60 分間に生成するオレイン酸の $\mu \mathrm{Eq}$ で示した。酵素液のタンパク質濃度は, Pierce 製 の BCA Protein assay reagentを使用して測定した。

2.3 肝臓の $7 \alpha$-ヒドロキシラーゼ $\mathrm{mRNA}$ の発現量 および HMG-CoA レダクターゼ mRNA の発現量の測 定 ラット 5 匹について前報 ${ }^{25)}$ と同様に 5 匹について 測定し， $\beta$-アクチン mRNA 発現量に対する比率として 数值化した。

2.4 脂肪組織のリポプロテインリパーゼ活性の測定 脂肪組織（腎周囲および副睪丸周囲脂肪組織）の LPL は Masuno et al. ${ }^{26)}$ の方法に準じて既報 ${ }^{19)}$ と同様に測定 
Table 3 Effects of surfactin and natto on body weight and abdominal adipose tissue weight of rats.

\begin{tabular}{|c|c|c|c|}
\hline Group & $\begin{array}{c}\text { Bodyweight gain }{ }^{1} \\
(\%)\end{array}$ & $\begin{array}{c}\text { Perirenal adipose tissue } \\
(\%)^{2}\end{array}$ & $\begin{array}{c}\text { Epididymal adipose tissue } \\
(\%)^{2}\end{array}$ \\
\hline Control & $131 \pm 1^{\text {ab }}$ & $1.8 \pm 0.3$ & $1.5 \pm 0.1$ \\
\hline Surfactin & $132 \pm 1^{\mathrm{a}}$ & $1.4 \pm 0.0$ & $1.4 \pm 0.0$ \\
\hline Natto & $126 \pm 1^{\mathrm{b}}$ & $1.6 \pm 0.1$ & $1.3 \pm 0.1$ \\
\hline Surfactin-Natto & $135 \pm 1^{\mathrm{a}}$ & $1.8 \pm 0.0$ & $1.5 \pm 0.0$ \\
\hline \multicolumn{4}{|l|}{ Two-way ANOVA } \\
\hline Surfactin & $p<0.001$ & ns & ns \\
\hline Natto & ns & ns & $\mathrm{ns}$ \\
\hline Surfactin-Natto & $p<0.01$ & ns & ns \\
\hline
\end{tabular}

${ }^{1}$ Expressed as \% of the initial weight. ${ }^{2}$ Rate to the final body weight. Each value is the mean \pm SE for 6 rats. Values in the same column without common superscript letter are significantly different at $p<0.05$ by Turkey's HSD test. The effects of surfactin and natto supplementation and their interaction were analyzed by two-way ANOVA. ns, not significant.

した。酵素活性は総脂肪組織当たりおよびタンパク質 1 $\mathrm{mg}$ 当たりの生成オレイン酸 $\mu \mathrm{Eq}$ で表した。

2.5 脂肪組織のリポプロテインリパーゼ mRNA の 発現量の測定 既報 ${ }^{19)}$ と同様にラット 5 匹について測 定し, mRNA 発現量を $\beta$-アクチン mRNA 発現量に対 する比率として数值化した。

2.6 糞中コレステロールの測定 既報 ${ }^{19)}$ と同様に Zak-Henly 法 ${ }^{27)}$ で測定し, 飼料摂取量から求めたコレ ステロール摂取量に対する幘中コレステロール排泄量の 比率を貨中コレステロール排泄率とした。

2.7 翼中胆汁酸の測定 Eaton \& Klaassenの方 法 $^{28)}$ によって測定した。すなわち翼風乾物に純エ夕 ノールを加え, $70^{\circ} \mathrm{C} 1$ 時間の抽出を 3 回繰り返して胆 汁酸測定用抽出液を調製した。測定は hydroxysteroid dehydrogenase が $\mathrm{NAD}^{+}$存在下で特異的にタウロコー ル酸ナトリウムを3-オキソ体に変換し，このとき 340 $\mathrm{nm}$ に吸収をもつ NADH が生成されることを利用し て, 抽出液の酵素添加前後に扔ける $340 \mathrm{~nm}$ の吸収の差 から胆汁酸量を求めた。

\section{3. 統 計処 理}

データは統計ソフト (SPSS, ver11.0J Windows XP) を使用してANOVAによる検定後, Turkeyの HSD テストによって群間の有意差（ $p<0.05 ）$ を判定した。 またサーファクチンと納豆の相乗効果については, 二元 配置分散分析法により判定した。なお百分率デー夕につ いては，逆正弦変換した値を用いて判定した。

\section{実 験 結 果}

\section{1. 体重増加率および脂肪組織量}

エネルギー摂取量をそろえて各群ペアフィーディング したが，体重増加率は納豆群が最も低い值を示した。対 照群に比べて三つの試験群ではいずれも有意差がなかっ た。脂肪組織の対体重比は腎周囲脂肪組織, 副睪丸周囲 脂肪組織とも群間に有意差はなかった（Table 3)。

\section{2. 血清および肝臓の脂質濃度}

血清 T-chol は, 対照群に比べて 3 試験群のいずれに おいても低值を示し, サーファクチン・納豆群で最も低 く, サーファクチンと納豆の相乗効果が認められた。 HDL-chol も T-chol と同様，3 試験群いずれに抢いて も低値となりサーファクチンと納豆の相乗効果が認めら れた。AI と TG は対照群に比べて納豆群, サーファク チン・納豆群で有意に低下したが，サーファクチンと納 豆の相乗効果は認められなかった (Table 4)。

肝臟の脂質含量は, Table 5 に示したとおりである。 TL はサーファクチン群, 納豆群で低下傾向を示し, サーファクチン・納豆群では有意に低值となった。Chol はサーファクチン群とサーファクチン・納豆群で顕著な 低值を示し，サーファクチンの効果が著しかった。 TG は試験群いずれにおいても低值となり, 統計学的には サーファクチンと納豆の相乗効果が認められた。肝臟の 対体重比は試験群のいずれもが低值を示したが，特に サーファクチン群とサーファクチン・納豆群で低く, サーファクチンの効果が大きかった。以上のように肝㵴 脂質はいずれも試験群で低下または低下傾向を示してお り, 肝臟脂質含量と肝臓の対体重比は類似した変化を示 した。

\section{3. 肝臟の脂質代謝系酵素活性}

脂肪酸合成系の律速酵素である ACC の活性はサー ファクチン群で低下傾向がみられた。納豆群では有意に 低くなり，サーファクチン・納豆群でさらに低下した。 FAS 活性はサーファクチン群で低下傾向がみられ, 納 豆群とサーファクチン・納豆群では有意に低值を示し, 納豆の影響が大きかった。HTGL 活性は, サーファク チン群でのみ有意に低值を示した（Table 6)。

4. 肝臓の $7 \alpha$-ヒドロキシラーゼ mRNA 発現量およ び HMG-CoA レダクターゼ mRNA 発現量

$7 \alpha$-ヒドロキシラーゼ mRNA の発現量はサーファク チン群で低值を示し, サーファクチン・納豆群とは有意 な差がみられた。HMG-CoA レダクターゼ mRNA の発 
Table 4 Effects of surfactin and natto on serum lipid concentration of rats.

\begin{tabular}{lcccc}
\hline \hline \multicolumn{1}{c}{ Group } & $\begin{array}{c}\text { Total cholesterol } \\
(\mathrm{mg} / \mathrm{dL})\end{array}$ & $\begin{array}{c}\text { HDL-cholesterol } \\
(\mathrm{mg} / \mathrm{dL})\end{array}$ & $\begin{array}{c}\text { Arteriosclerosis } \\
\text { index }^{1}\end{array}$ & $\begin{array}{c}\text { Triglycerides } \\
(\mathrm{mg} / \mathrm{dL})\end{array}$ \\
\hline Control & $221.4 \pm 30.9^{\mathrm{a}}$ & $38.8 \pm 2.3^{\mathrm{a}}$ & $4.8 \pm 0.8^{\mathrm{a}}$ & $60.2 \pm 7.1^{\mathrm{a}}$ \\
Surfactin & $94.1 \pm 10.2^{\mathrm{b}}$ & $23.7 \pm 2.2^{\mathrm{b}}$ & $3.3 \pm 0.9^{\mathrm{ab}}$ & $58.0 \pm 5.2^{\mathrm{a}}$ \\
Natto & $78.3 \pm 9.0^{\mathrm{b}}$ & $25.0 \pm 1.3^{\mathrm{b}}$ & $2.2 \pm 0.3^{\mathrm{b}}$ & $26.4 \pm 1.3^{\mathrm{b}}$ \\
Surfactin-Natto & $63.6 \pm 4.2^{\mathrm{b} *}$ & $22.7 \pm 3.0^{\mathrm{b}}$ & $2.0 \pm 0.3^{\mathrm{b}}$ & $30.3 \pm 1.7^{\mathrm{b}}$ \\
Two-way ANOVA & & & $\mathrm{ns}$ & $\mathrm{ns}$ \\
$\quad$ & $p<0.001$ & $p<0.01$ & $p<0.01$ & $p<0.001$ \\
$\quad$ Surfactin & $p<0.001$ & $p<0.01$ & $\mathrm{~ns}$ & $\mathrm{~ns}$ \\
$\quad$ Natto & $p<0.01$ & $p<0.05$ & & \\
\hline \hline
\end{tabular}

${ }^{1}$ (Total cholesterol-HDL-cholesterol)/HDL-cholesterol. Each value is the mean \pm SE for 6 rats. Values in the same column without common superscript letter are significantly different at $p<0.05$ by Turkey's HSD test.

* Expresses the synergistic effect. The effects of surfactin and natto supplementation and their interaction were analyzed by two-way ANOVA. ns, not significant.

Table 5 Effects of surfactin and natto on liver weight and liver lipid content of rats.

\begin{tabular}{|c|c|c|c|c|c|}
\hline \multirow{2}{*}{ Group } & \multicolumn{2}{|c|}{ Liver } & \multirow{2}{*}{$\begin{array}{c}\text { Total lipid } \\
\text { (mg/g tissue) }\end{array}$} & \multirow{2}{*}{$\begin{array}{c}\text { Cholesterol } \\
\text { (mg/g tissue) }\end{array}$} & \multirow{2}{*}{$\begin{array}{l}\text { Triglycerides } \\
\text { (mg/g tissue) }\end{array}$} \\
\hline & (g) & $(\%)^{1}$ & & & \\
\hline Control & $21.2 \pm 0.6^{\mathrm{a}}$ & $5.6 \pm 0.2^{\mathrm{a}}$ & $279 \pm 12^{\mathrm{a}}$ & $115 \pm 3^{\mathrm{a}}$ & $123 \pm 2^{\mathrm{a}}$ \\
\hline Surfactin & $16.0 \pm 0.4^{\mathrm{c}}$ & $4.3 \pm 0.1^{\mathrm{c}}$ & $260 \pm 10^{\mathrm{ab}}$ & $89 \pm 3^{b}$ & $88 \pm 4^{\mathrm{b}}$ \\
\hline Natto & $18.9 \pm 0.6^{\mathrm{b}}$ & $4.9 \pm 0.1^{b}$ & $256 \pm 6^{\mathrm{ab}}$ & $109 \pm 4^{\mathrm{ac}}$ & $79 \pm 4^{\mathrm{b}}$ \\
\hline Surfactin-Natto & $16.8 \pm 0.4^{\mathrm{c}}$ & $4.5 \pm 0.1^{\mathrm{bc}}$ & $240 \pm 8^{b}$ & $99 \pm 2^{\mathrm{bc}}$ & $88 \pm 4^{\mathrm{b} *}$ \\
\hline \multicolumn{6}{|l|}{ Two-way ANOVA } \\
\hline Surfactin & $p<0.001$ & $p<0.001$ & ns & $p<0.001$ & $p<0.05$ \\
\hline Natto & $\mathrm{ns}$ & ns & $p<0.05$ & $\mathrm{~ns}$ & $p<0.001$ \\
\hline Surfactin-Natto & $p<0.01$ & $p<0.01$ & ns & $p<0.01$ & $p<0.001$ \\
\hline
\end{tabular}

${ }^{1}$ Rate to the final body weight. Each value is the mean \pm SE for 6 rats. Values in the same column without common superscript letter are significantly different at $p<0.05$ by Turkey's HSD test. * Expresses the synergistic effect. The effects of surfactin and natto supplementation and their interaction were analyzed by two-way ANOVA. ns, not significant.

Table 6 Effects of surfactin and natto on the activities of acetyl CoA carboxylase, fatty acid synthase and hepatic triglyceride lipase in liver of rats.

\begin{tabular}{lccc}
\hline \hline \multicolumn{1}{c}{ Group } & $\begin{array}{c}\text { ACC } \\
\text { (unit/mg protein) }\end{array}$ & $\begin{array}{c}\text { FAS } \\
\text { (unit/mg protein) }\end{array}$ & $\begin{array}{c}\text { HTGL } \\
(\mu \text { Eq/mg protein) }\end{array}$ \\
\hline Control & $0.083 \pm 0.004^{\mathrm{a}}$ & $0.0037 \pm 0.0003^{\mathrm{a}}$ & $0.072 \pm 0.002^{\mathrm{a}}$ \\
Surfactin & $0.075 \pm 0.013^{\mathrm{ac}}$ & $0.0030 \pm 0.0002^{\mathrm{a}}$ & $0.039 \pm 0.002^{\mathrm{b}}$ \\
Natto & $0.061 \pm 0.002^{\mathrm{bc}}$ & $0.0015 \pm 0.0001^{\mathrm{b}}$ & $0.079 \pm 0.003^{\mathrm{a}}$ \\
Surfactin-Natto & $0.050 \pm 0.002^{\mathrm{b}}$ & $0.0018 \pm 0.0000^{\mathrm{b}}$ & $0.078 \pm 0.005^{\mathrm{a}}$ \\
Two-way ANOVA & & & $p<0.001$ \\
$\quad$ Surfactin & $p<0.01$ & $\mathrm{~ns}$ & $p<0.001$ \\
Natto & $p<0.001$ & $p<0.001$ & $p<0.001$ \\
Surfactin-Natto & $\mathrm{ns}$ & $p<0.05$ & \\
\hline \hline
\end{tabular}

Each value is the mean \pm SE for 6 rats. Value in the same column without common superscript letter are significantly different at $p<0.05$ by Turkey's HSD test. The effects of surfactin and natto supplementation and their interaction were analyzed by two-way ANOVA. ns, not significant. Abbreviations: ACC, acetyl CoA carboxylase; FAS, fatty acid synthase; HTGL, hepatic triglyceride lipase.

現量は各群間で有意な差がみられなかった（Table 7)。

5. 脂肪組織の LPL 活性および LPLmRNA 発現量

酵素タンパク質 $1 \mathrm{mg}$ 当たりおよび全脂肪組織当たり

の LPL 活性は，対照群に比してサーファクチン群で有
意に低値を示したが，納豆投与による影響は認められな かった。LPLmRNA 発現量は各群間で有意差がなかっ た(Table 8)。 
Table 7 Effects of surfactin and natto on $7 \alpha$ hydroxylase mRNA and HMG-CoA reductase mRNA in liver of rats.

\begin{tabular}{lcc}
\hline \hline \multicolumn{1}{c}{ Group } & $\begin{array}{c}7 \alpha \text {-hydroxylase } \\
\text { mRNA/ } \beta \text {-actin } \\
\text { mRNA }\end{array}$ & $\begin{array}{c}\text { HMG-CoA } \\
\text { reductase } \\
\text { mRNA/ } \beta \text {-actin } \\
\text { mRNA }\end{array}$ \\
\hline Control & $1.33 \pm 0.33^{\mathrm{ab}}$ & $0.43 \pm 0.13$ \\
Surfactin & $0.60 \pm 0.15^{\mathrm{a}}$ & $0.57 \pm 0.14$ \\
Natto & $1.08 \pm 0.29^{\mathrm{ab}}$ & $0.37 \pm 0.05$ \\
Surfactin-Natto & $1.30 \pm 0.19^{\mathrm{b}}$ & $0.36 \pm 0.02$ \\
Two-way ANOVA & & \\
Surfactin & $\mathrm{ns}$ & $\mathrm{ns}$ \\
Natto & $\mathrm{ns}$ & $\mathrm{ns}$ \\
Surfactin-Natto & $\mathrm{ns}$ & $\mathrm{ns}$ \\
\hline \hline
\end{tabular}

The amounts of both mRNA's are expressed as the ratio to $\beta$-actin mRNA. Each value is the mean $\pm \mathrm{SE}$ for 5 rats. Values in the same column without common superscript letter are significantly different at $p<0.05$ by Turkey's HSD test. The effects of surfactin and natto supplementation and their interaction were analyzed by two-way ANOVA. ns, not significant. Abbreviation: HMG-CoA, $\beta$-hydroxy$\beta$-methylglutaryl coenzyme A.

\section{6. 董量, 粪中コレステロール排泄率および胆汁酸排 泄量}

糞量は納豆の影響を強く受け，納豆群，サーファクチ ン・納豆群で有意に増加した。Chol 排泄率は対照群に 比べてサーファクチン群, 納豆群で増加傾向を示し, サーファクチン・納豆群で有意に増加して, サーファク チンと納豆の相乗効果がみられた。胆汁酸排泄量は対照 群に比べてサーファクチン群くサーファクチン・納豆 群<納豆群の順に増加し，納豆の影響が大きかった (Table 9)。

\author{
考察 \\ サーファクチンは 1968 年に枯草菌 (Bacillus subtilis)
} の培養液から結晶化されたバイオサーファクタントで, 多様な生物活性を有している ${ }^{1-3)}$ 。Imai et $a l^{4}{ }^{4)}$ はサー ファクチン $0.3 \%$ 添加高コレステロール食で飼育した ラットを用いて，コレステロールの吸収阻害および血 漿，肝臓のコレステロールレベルの低下を報告してい る。一方，サーファクチンを微量生産する納豆菌を使用 して大豆から作られる納豆には，脂質代謝を改善する作 用がいくつか報告されている。そこで本研究において は，納豆にサーファクチンを $0.3 \%$ 添加した飼料を用い て納豆の脂質代謝改善に及ぼすサーファクチンの効果を ラットを用いて検討した。

血中の T-chol, AI, TGとも対照群に比して試験群 で改善された。T-chol の改善にはサーファクチンと納 豆の相乗効果が認められ, TG の改善には納豆の効果が 大きかった。肝蔵Cholについても, 試験群で低下の傾 向または有意な低下を示した。Imai et $a l .{ }^{4)}$ はサーファ クチンがラット消化管から吸収されないことを認め，血 中および肝臓コレステロールの低下がサーファクチンに よるコレステロールの吸収阻害にあると推定している。 本研究では糞中 Chol 排泄率はサーファクチン群で増加 傾向を示したが，対照群と比べ有意な差は認められな かった。

著者らは以前, 界面活性作用のあるユッカサポニンお よび大豆サポニンについて，脂質代謝への影響を検討 し，ユッカサポニンが著しく翼中 Chol 排泄率を増加さ せて, 血清と肝臓の Chol レベルを低下するのに対し, 大豆サポニンは本研究の納豆群と同様に Chol 排泄率を ほとんど増加せず，血清 Chol レベルのみ低下すること を報告した ${ }^{20)}$ 。既報 ${ }^{20)}$ では，胆汁酸排泄量を測定しな かったが, 本研究において胆汁酸排泄量を測定した結 果, 納豆群, サーファクチン・納豆群でそれぞれ対照群,

Table 8 Effects of surfactin and natto on the activity of lipoprotein lipase and its mRNA amount in abdominal adipose tissue of rats.

\begin{tabular}{|c|c|c|c|}
\hline Group & $\begin{array}{c}\mathrm{LPL} \\
(\mu \mathrm{Eq} / \text { total adipose tissue })\end{array}$ & $\begin{array}{c}\mathrm{LPL} \\
(\mu \mathrm{Eq} / \mathrm{mg} \text { protein })\end{array}$ & LPL mRNA/ $\beta$-actin $\mathrm{mRNA}^{1}$ \\
\hline Control & $5.5 \pm 0.6^{\mathrm{a}}$ & $0.14 \pm 0.01^{\mathrm{a}}$ & $25.9 \pm 5.1$ \\
\hline Surfactin & $3.5 \pm 0.3^{b}$ & $0.07 \pm 0.00^{\mathrm{b}}$ & $26.1 \pm 7.6$ \\
\hline Natto & $5.9 \pm 0.6^{\mathrm{a}}$ & $0.16 \pm 0.01^{\mathrm{a}}$ & $33.3 \pm 8.8$ \\
\hline Surfactin-Natto & $5.1 \pm 0.4^{\mathrm{ab}}$ & $0.12 \pm 0.01^{\mathrm{a}}$ & $18.6 \pm 4.2$ \\
\hline \multicolumn{4}{|l|}{ Two-way ANOVA } \\
\hline Surfactin & $p<0.01$ & $p<0.001$ & ns \\
\hline Natto & ns & $p<0.01$ & ns \\
\hline Surfactin-Natto & ns & ns & ns \\
\hline
\end{tabular}

${ }^{1}$ This value is the mean \pm SE for 5 rats. Other values are the mean \pm SE for 6 rats. Values in the same column without common superscript letter are significantly different at $p<0.05$ by Turkey's HSD test. The effects of surfactin and natto supplementation and their interaction were analyzed by two-way ANOVA. ns, not significant. Abbreviation: LPL, lipoprotein lipase. 
Table 9 Effects of surfactin and natto on fecal excretion of cholesterol and cholic acid in rats.

\begin{tabular}{lccc}
\hline \hline \multicolumn{1}{c}{ Group } & $\begin{array}{c}\text { Amount of Feces } \\
(\mathrm{g} / \text { 3days })\end{array}$ & $\begin{array}{c}\text { Cholesterol excretion } \\
(\% \text { of ingestion })\end{array}$ & $\begin{array}{c}\text { Cholic acid excretion } \\
(\mu \mathrm{mol} / \text { day })\end{array}$ \\
\hline Control & $3.4 \pm 0.1^{\mathrm{b}}$ & $37.4 \pm 1.3^{\mathrm{b}}$ & $14 \pm 1^{\mathrm{d}}$ \\
Surfactin & $3.4 \pm 0.1^{\mathrm{b}}$ & $39.8 \pm 1.6^{\mathrm{b}}$ & $45 \pm 4^{\mathrm{c}}$ \\
Natto & $8.4 \pm 0.4^{\mathrm{a}}$ & $38.7 \pm 1.3^{\mathrm{b}}$ & $103 \pm 6^{\mathrm{a}}$ \\
Surfactin-Natto & $8.3 \pm 0.1^{\mathrm{a}}$ & $48.0 \pm 0.8^{\mathrm{a} *}$ & $65 \pm 2^{\mathrm{b}}$ \\
Two-way ANOVA & & & $\mathrm{ns}$ \\
$\quad$ Surfactin & $\mathrm{ns}$ & $p<0.001$ & $p<0.001$ \\
$\quad$ Natto & $p<0.001$ & $p<0.01$ & $p<0.001$ \\
Surfactin-Natto & $\mathrm{ns}$ & $p<0.05$ & \\
\hline \hline
\end{tabular}

Each value is the mean \pm SE for 6 rats. Values in the same column without common superscript letter are significantly different at $p<0.05$ by Turkey's HSD test. * Expresses the synergistic efffect. The effects of surfactin and natto supplementation and their interaction were analyzed by two-way ANOVA. ns, not significant.

Table 10 Analysis of interactions between surfactin and natto by two-way ANOVA.

\begin{tabular}{|c|c|c|c|}
\hline Item & Surfactin & Natto & Surfactin and Natto \\
\hline Bodyweight gain (\%) & $p<0.001$ & ns & $p<0.01$ \\
\hline Liver weight $(g)$ & $p<0.001$ & ns & $p<0.01$ \\
\hline Liver rate to the bodyweight $(\%)$ & $p<0.001$ & $\mathrm{~ns}$ & $p<0.01$ \\
\hline Serum Total cholesterol (mg/dL) & $p<0.001$ & $p<0.001$ & $p<0.01^{*}$ \\
\hline HDL-cholesterol (mg/dL) & $p<0.01$ & $p<0.01$ & $p<0.05^{*}$ \\
\hline Arteriosclerosis index & ns & $p<0.01$ & ns \\
\hline Triglycerides (mg/dL) & ns & $p<0.001$ & ns \\
\hline Liver Total lipid (mg/g) & ns & $p<0.05$ & ns \\
\hline Cholesterol (mg/g) & $p<0.001$ & ns & $p<0.01$ \\
\hline Triglycerides (mg/dL) & $p<0.05$ & $p<0.001$ & $p<0.001^{*}$ \\
\hline ACC (unit/mg protein) & $p<0.01$ & $p<0.001$ & $\mathrm{~ns}$ \\
\hline FAS (unit/mg protein) & ns & $p<0.001$ & $p<0.05$ \\
\hline HTGL $(\mu \mathrm{Eq} / \mathrm{mg}$ protein $)$ & $p<0.001$ & $p<0.001$ & $p<0.001$ \\
\hline Abdominal adipose tissue LPL ( $\mu \mathrm{Eq} /$ total tissue) & $p<0.01$ & $\mathrm{~ns}$ & ns \\
\hline LPL $(\mu \mathrm{Eq} / \mathrm{mg}$ protein $)$ & $p<0.001$ & $p<0.01$ & ns \\
\hline Feces Amount (g/3 days) & ns & $p<0.001$ & ns \\
\hline Cholesterol excretion (\% of ingestion) & $p<0.001$ & $p<0.01$ & $p<0.05^{*}$ \\
\hline Cholic acid excretion ( $\mu \mathrm{mol} / \mathrm{day})$ & ns & $p<0.001$ & $p<0.001$ \\
\hline
\end{tabular}

${ }^{*}$ Expresses the synergistic effet. ns, not signifcant. Abbreviations: ACC, acetyl CoA carboxylase; FAS, fatty acid synthase; HTGL, hepatic triglyceride lipase; LPL, lipoprotein lipase.

サーファクチン群より増加し, Oakenfull et al. ${ }^{11)}$, Sidhu \& Oakenfull ${ }^{29)}$ の報告と同様，大豆サポニンの影響によ ると考えられた。

コレステロールの合成系に関係する HMG-CoA レダ クターゼ mRNAの発現量は各群間で有意な差がなく, コレステロールの異化系に関係する $7 \alpha$-ヒドロキシラー ゼ mRNAの発現量にもサーファクチンと納豆の影響は 認められなかった。したがって試験群における血清およ び肝臓 Chol レベルの低下について, サーファクチン・ 納豆群では䔬中コレステロール排泄率および胆汁酸排泄 量の増加が, またサーファクチン群, 納豆群では胆汁酸 排泄量の増加が関与したと考えられる。

血清 TGレベルは納豆群, サーファクチン・納豆群 で顕著な低值を示し, 納豆の効果が明白であった。これ
は肝臓の脂肪酸合成系酵素活性の低下による肝臓から血 中への VLDL 放出の低下 ${ }^{30)}$ が影響したためと思われ る。サーファクチン群で血清 TGレベルの低下がみら れなかったのは，血中脂肪の取り込みに関与する脂肪組 織の LPL 活性および肝蔵の HTGL 活性が低下してい たためと推察される。

脂肪酸合成の律速酵素である ACC 活性は, 試験群で 低下し，FAS 活性も同様に低下し，特に納豆の影響が 顕著であった。これは Sugano et $a l .{ }^{30)}$, Iritani et $a l .{ }^{31)}$ が報告している大豆タンパク質による肝臓の脂肪酸合成 系酵素活性の低下と一致している。三つの試験群におけ る肝蔵 TGの低下については, 納豆群, サーファクチ ン・納豆群では肝臓の脂肪酸合成系酵素活性の低下が, またサーファクチン群では血中脂肪の取り込みに関与す 
る HTGL 活性の低下がそれぞれ影響したものと思われ る。

糞排泄量が納豆群，サーファクチン・納豆群で増加し たのは，飼料にセルロースを添加せずに調製したにもか かわらず，食物繊維量が対照群，サーファクチン群の飼 料に比べて約 7\%多かったためと思われる。

大豆については, 構成アミノ酸類 ${ }^{32)}$, サポニン ${ }^{11) 12129) 33)}$, イソフラボン ${ }^{34)}$ などによるコレステロールの吸収抑 制13)1435) に基づいて，血清 Chol が低下するとする報告 が数多くある。これに対して, 納豆については, ビタミ ン $\mathrm{B}_{2}, \mathrm{~K}_{2}$ の増加, 大豆の消化吸収率の上昇, ポリグル 夕ミン酸からなる粘質物の効用, ナットウキナーゼによ る血栓溶解作用, 抗酸化作用 ${ }^{16)}$ など種々の機能が知ら れているものの, 脂質代謝改善に関しては血中 T-chol と $\mathrm{TG}^{15) 36)}$ の減少および肝細胞中の脂肪滴の減少 ${ }^{36)}$ が 知られている程度で，あまり報告がない。

今回著者らはラットを用いて納豆の脂質代謝改善作用 を詳細に検討し，その有用性を明らかにすることができ た。そして納豆にバイオサーファクタントの一種である サーファクチンを添加することによって, 血清 T-chol と肝臓 TGの減少および䔬中コレステロール排泄率の 増加に相乗的効果がもたらされることを認めた。

\section{文献}

1) Arima K, Kakinuma A, Tamura G (1968) Surfactin, a crystalline peptidelipid surfactant produced by Bacillus subtilis: Isolation, characterization and its inhibition of fibrin clot fermation. Biochem Biophys Res Commun 31 : 488-94.

2) 垣沼淳司 (2001) サーファクチン発酵：醱酵ハンド ブック（バイオインダストリー協会編）, p. 193-4. 共立出版, 東京.

3）垣沼淳司, 有馬 啓 (1969) サーファクチンーBacillus subtilis の生産する新界面活性ペプチドリピド. 武田研究所年報 28, 140-93.

4) Imai Y, Sugino H, Fujita T, Kakinuma A (1971) Hypocholesterolemic effect of surfactin, a novel bacterial peptidelipid. $J$ Takeda Res Lab 30 : 728-34.

5) Sirtori CR, Lobati MR, Manzoni C, Monetti M, Pazzucconi F, Gatti E (1995) Soy and cholesterol reduction; Clinical experience. J Nutr 125 : 598S$605 \mathrm{~S}$.

6) Anderson JW, Johnstone BM, Cook-Newell ME (1995) Meta-analysis of the effects of soy protein intake on serum lipids. $N$ Engl J Med $333: 276$ 82.

7）秋岡 壽, 加藤一彦，藤井富美子，大和信也，青山 敏明，津村治男（2000）豆乳の摂取が血清コレステ ロール高值者の血清脂質に及ぼす影響。健康・栄養 食品研究 3, 37-46.

8）山本孝史, 井上五郎（1991）ヒト血墏コレステロー ル濃度に及ぼす大豆タンパク質の効果. 日本栄養 ・ 食糧学会誌 44, 155-62.
9）菅野道廣（1987）コレステロール代謝の調節に関す る栄養生化学的研究 食餌タンパク質の影響. 日本 栄養・食糧学会誌 40, 93-102.

10）佐伯 茂，金内 理，細谷恵理，桐山修八（1989） 大豆たん白質による肝コレステロール濃度の調節機 構. 大豆たん白質栄養研究会会誌 10, 53-7.

11) Oakenfull DG, Topping DL, Illman RJ, Fenwick DE (1984) Prevention of dietary hypercholesterolaemia in the rat by soya bean and Quillaja saponins. Nutr Rep Int 29:1039-46.

12) Sugano M, Goto S, Yamada $Y$, Yoshida K, Hashimoto Y, Matsuo T, Kimoto M (1990) Cholesterollowering activity of various undigested fraction of soybean protein in rats. J Nutr 120:977-85.

13）奥田豊子，三好弘子，山本由美子，浅田敏枝，上田 真弓，早川奈津実，小石秀夫（1987）七トの分離大 豆タンパク質摂取時におけるコレステロール排泄お よび血漿コレステロール濃度. 大豆たん白質栄養研 究会会誌 8, 93-7.

14) Chi Y-S, Goto S, Ikeda I, Sugano M (1989) Interaction of dietary protein, cholesterol and age on lipid metabolism of the rat. Br J Nutr 61:53143.

15) Iwai K, Nakaya N, Kawasaki $Y$, Matsue $H$ (2002) The inhibitory effect of natto, a kind of fermented soybeans, on LDL oxidation in vitro. $J$ Agric Food Chem 50 : 3592-96.

16) Iwai K, Nakaya N, Kawasaki $Y$, Matsue $H$ (2002) Antioxidative functions of natto, a kind of fermented soybeans: Effect on LDL oxidation and lipid metabolism in cholesterol-fed rats. J Agric Food Chem 50:3597-601.

17）伊藤義文（1999）納豆菌に扔けるポリグルタミン酸 生産制御機構. バイオサイエンスとインンダストリー $57: 247-50$.

18) Harper AE (1959) Amino acid balance and imbalance, 1 . Dietary levels of protein and amino acid imbalance. J Nutr 68:405-18.

19）谷由美子，藤岡敏明，浜田博喜，国松已歳，古市幸 生（2003）バニリルノナンアミド- $\beta$-D-グルコシドに よる高脂血症ラットの血清脂質低下作用. 日本栄 養・食糧学会誌 56, 181-7.

20）辻原命子，谷由美子（1998）高脂肪高コレステロー ル食飼育ラットの脂質代謝におよぼすユッカサポニ ンおよびコンニャク精粉の影響. 日本栄養・食糧学 会誌 51, 157-63.

21) Nepokroeff CM, Lakshmamnan MR, Porter JW (1975) Fatty acid synthase from rat liver. Methods Enzymol 35 : 34-44.

22）仲佐輝子，山口真由美，沖中 靖，目鳥幸一，高橋 周士（1995）高脂肪高コレステロール食投与ラット の血漿および肝臓中の脂質に及ぼす杜仲茶抽出物の 影響. 日本農芸化学会誌 69, 1491-8.

23) Tanabe T, Nakanishi S, Hashimoto T, Ogiwara H, Nikawa J, Numa S (1981) Acetyl-CoA carboxylase from rat liver. Methods Enzymol 71:5-16.

24) Morimoto C, Tsujita T, Okuda H (1997) Norepinephrine-induced lipolysis in rat fat cells from 
visceral and subcutaneous sites; Role of hormonesensitive lipase and lipid droplets. $J$ Lipid Res $38: 132-8$.

25) Tani Y, Fujioka M, Sumioka Y, Furuichi Y, Hamada H, Watanabe T (2004) Effects of capsinoid on serum and liver lipids in hyperlipidemic rats. J Nutr Sci Vitaminol $50: 351-5$.

26) Masuno H, Blanchetle-Mackie EJ, Chernick SS, Scow RO (1990) Synthesis of inactive nonsecretable high mannose-type lipoprotein lipase by cultured brown adipocytes of combined lipasedeficient cld/cld mice. J Biol Chem 265 : 1628-38.

27）上田英夫（1969）臨床検査法，p. 398. 杏林書院，東 京.

28) Eaton DL, Klaassen CD (1976) Effects of acute administration of taurocholic and taurochenodeoxycholic acid on biliary lipid excretion in the rat. Proc Soc Exp Biol Med 151: 198-202.

29) Sidhu GS,Oakenfull DG (1986) A mechanism for the hypocholesterolaemic activity of saponins. $\mathrm{Br}$ J Nutr 55:643-49.

30) Sugano M, Tanaka K, Ide T (1982) Secretion of cholesterol, triglyceride and apolipoprotein A-1 by isolated perfused liver from rats fed soybean protein and casein or their amino acid mixtures. $J$
Nutr 112:855-62.

31) Iritani $N$, Hosomi $H$, Fukuda $H$, Tada $K$, Ikeda $H$ (1996) Soybean protein suppresses hepatic lipogenic enzyme gene expression in wistar fatty rats. $J$ Nutr 126:380-8.

32) Tasker TE, Potter SM (1993) Effects of dietary protein source on plasma lipids, HMGCoA reductase activity and hepatic glutathione levels in gerbils. J Nutr Biochem 4 : 458-62.

33) Ueda H, Matsumoto A, Goutani S (1996) Effects of soybean saponin and soybean protein on serum cholesterol concentration in cholesterol-fed chicks. Anim Sci Technol (Jpn) 67:415-22.

34) Potter SM (1995) Overview of proposed mechanisms for the hypocholesterolemic effect of soy. $J$ Nutr 125:606S-11S.

35) Nagata Y, Ishiwaki N, Sugano M (1982) Studies on the mechanism of antihypercholesterolemic action of soy protein and soy protein-type amino acid mixtures in relation to the casein counterparts in rats. $J$ Nutr $112: 1614-25$.

36) Ozawa H (2002) Morphological study of the parathyroid, thyroid, femur and liver of the rat fed high-cholesterol diet and natto. Acta Scholae Med. Univ. Gifu 50:20-6. 


\title{
Original Paper
}

\author{
Synergistic Effects of Surfactin and Natto in Lowering \\ the Serum and Liver Lipid Levels of \\ Rats Fed a High-fat Diet \\ Yumiko Tani, ${ }^{* 1}$ Sayaka Mizuno, ${ }^{2}$ Miyuki Sumioka, ${ }^{3}$ \\ Yukio Furuichi, ${ }^{1}$ Yoshifumi Ohshima, ${ }^{4}$ Takashi Fushimi, ${ }^{4}$ \\ and Atsushi Kakinuma ${ }^{2}$
}

(Received September 12, 2005 ; Accepted July 15, 2006)

\begin{abstract}
Summary: The present investigation was designed to determine whether any synergism exists between surfactin and natto in improving the lipid metabolism of rat. Rats were divided into four groups and fed four different diets each having a high cholesterol and lard content. The diet of the control group did not contain either surfactin or natto, whereas the three experimental groups were given a diet containing surfactin alone (surfactin group), natto alone (natto group), and a mixture of surfactin and natto (surfactin-natto group) . Analyses revealed that the levels of serum lipids, total cholesterol ( $\mathrm{T}$-chol), arteriosclerosis index (AI), and triacylglycerol (TG) were decreased significantly or tended to decrease in the three experimental groups. With regard to the amount of lipids in liver, total lipid (TL) was decreased in the surfactin-natto group, cholesterol was decreased in both the surfactin and the surfactin-natto groups, and TG was decreased in all the experimental groups. The cholesterol excretion ratio was increased in the surfactin-natto group and cholic acid excretion was markedly increased in all the experimental groups, while the enzyme activity responsible for lipid synthesis in the liver was decreased in the natto and surfactin-natto groups. These results indicate that surfactin and natto exhibit synergism in improving the lipid metabolism of rats by lowering the levels of serum T-chol and liver TG and by increasing the cholesterol excretion ratio, suggesting that the development of surfactin-rich natto would be of potential value.
\end{abstract}

Key words : surfactin, natto, serum lipids, liver lipids, synergism

* Corresponding author

${ }^{1}$ Faculty of Home Economics, The Nagoya Women's University, 3-40 Shioji-cho, Mizuho-ku, Nagoya, Aichi 467-0003, Japan

2 Formerly, The Nagoya Women's University

${ }^{3}$ Faculty of Bioresources, Mie University, 1577 Kuriyamamachiya-cho, Tsu, Mie 514-8507, Japan

${ }^{4}$ Central Research Institute, Mitsukan Group Co., Ltd., 2-6 Nakamura-cho, Handa, Aichi 475-8585, Japan 